Wyższa Szkoła Administracji i Biznesu im. E. Kwiatkowskiego w Gdyni

\title{
PRAWO DO ROKOWAŃ ZBIOROWYCH - PRAWO PRACOWNIKÓW CZY ZWIĄZKÓW ZAWODOWYCH?
}

\begin{abstract}
Right to collective bargaining - the right of workers or trade unions?

In this article the author examines the right to collective bargaining, which is regarded as a fundamental principle of collective labour law and seeks to answer the question whether the right to collective bargaining and the conclusion of collective agreements or arrangements is an emanation of the freedom of association in trade unions or rather amounts to a separated (from the freedom of association) right of employees represented by collective labour law bodies, including trade unions. To this end, the author examines regulations on collective bargaining in international and national law. The aforementioned analysis enabled to conclude that it cannot be unequivocally stated that the right to collective bargaining is granted exclusively to trade unions. At the same time the author states that this right is perceived as one aspect of the freedom of association and cannot be realized by employees directly (individually). Based on the aforesaid analysis the author also formulates proposals for changes in the Polish collective labour legislation.
\end{abstract}

Słowa kluczowe: rokowania zbiorowe, układy zbiorowe pracy, związki zawodowe, przedstawicielstwo pracowników

Key words: collective bargaining, collective agreement, trade unions, employee representation

\section{Wprowadzenie}

Prawo do rokowań zbiorowych uważane jest za podstawową zasadę zbiorowego prawa pracy $^{1}$. Przyjmuje się, że jego istotę stanowi możliwość zawierania układów zbiorowych pracy pomiędzy pracodawcami i organizacjami pracodawców a organizacjami pracowników w celu uregulowania w ten sposób warunków pracy².

1 G. Goździewicz, Układy zbiorowe pracy jako podstawowy instrument działalności związków zawodowych, w: Zbiorowe prawo pracy w XXI wieku, J. Stelina, M. Tomaszewska, A. Wypych-Żywicka (red.), Gdańsk 2010, s. 96.

2 Z. Hajn, Zbiorowe prawo pracy. Zarys systemu, Warszawa 2013, s. 35. 
Mając na uwadze różnorodność aktów stanowiących owoc rokowań zbiorowych, warto postawić pytanie, czy prawo do prowadzenia rokowań zbiorowych i zawierania układów lub porozumień zbiorowych stanowi emanację wolności zrzeszania się w związkach zawodowych, czy też stanowi odrębne od wolności związkowej prawo pracowników reprezentowanych przez podmioty zbiorowego prawa pracy, w tym związki zawodowe.

Podejmując próbę odpowiedzi na tak postawione pytanie, wypada rozpocząć od zwięzłego przeglądu regulacji w zakresie rokowań zbiorowych w prawie międzynarodowym i krajowym.

\section{Międzynarodowa Organizacja Pracy}

Międzynarodowa Organizacja Pracy odgrywa szczególną rolę w sferze stanowienia standardów międzynarodowych w zakresie zbiorowego prawa pracy ${ }^{3}$. Już Deklaracja Filadelfijska z 1944 r. wymienia - upowszechnianie programów mających na celu osiągnięcie efektywnego korzystania z prawa do rokowań zbiorowych jako jedno $\mathrm{z}$ uroczystych zobowiązań $\mathrm{MOP}^{4}$. Wśród konwencji regulujących zagadnienie prawa do rokowań zbiorowych należy wymienić Konwencję nr 98 z 1949 r. dotyczącą zasad prawa zrzeszania się i prowadzenia rokowań zbiorowych oraz Konwencję nr 154 z 1983 r. dotyczącą popierania rokowań zbiorowych. Konwencje te są uznawane za traktaty zawierające prawa człowieka ${ }^{5}$.Zakres obowiązku promowania układów zbiorowych pracy został rozszerzony na państwa, które nie ratyfikowały Konwencji nr $98^{6}$. W myśl art. 4 Konwencji nr 98 MOP należy zastosować środki odpowiadające warunkom krajowym $\mathrm{w}$ celu zachęcania i popierania jak najszerszego rozwoju i wykorzystywania procedury dobrowolnych rokowań dla zawierania układów zbiorowych pomiędzy pracodawcami i organizacjami pracodawców z jednej strony a organizacjami pracowników z drugiej, w celu uregulowania w ten sposób warunków pracy.

Pojęcie rokowań zbiorowych pojawia się także w art. 2 Konwencji MOP nr 154, zgodnie z którym termin „rokowania zbiorowe” dotyczy wszystkich negocjacji następujących między pracodawcą, grupą pracodawców albo co najmniej jedną organizacją pracodawców z jednej strony i co najmniej jedną organizacją pracowników z drugiej, w celu: (a) określenia warunków pracy i zatrudnienia; i/lub (b) uregulowania stosunków

3 J. Murray, Taking Social Rights Seriously: Is There a Case for Institutional Reform of the ILO?, w: Human Rights at Work. Perspectives on Law and Regulation, T. Novitz, C. Fenwick (red.), Oxford-Portland, Oregon, 2010, s. 376; A.M. Świątkowski, Międzynarodowe prawo pracy, t. I, Międzynarodowe publiczne prawo pracy. Wolumen 1, Warszawa 2008, s. 10.

4 http://www.mop.pl/doc/pdf/inne/dekfil.pdf (dostęp: 1.03.2017).

${ }^{5}$ C. Kaufmann, The Conflict between Core Labour Rights and International Economic Law, Oxford 2007, s. 52; P. Alston, „Core Labour Standards” and the Transformation of the International Labour Rights Regime, w: V.A. Leary, D. Warner, Social Issues, Globalisation and International Institutions. Labour Rights and the EU, ILO, OECD and WTO, Leiden-Boston 2006, s. 3.

${ }_{6}^{6}$ A.M. Świątkowski, Międzynarodowe prawo pracy..., s. 55. 
między pracodawcami a pracownikami; i/lub (c) uregulowania stosunków między pracodawcami lub ich organizacjami a organizacją lub organizacjami pracowników.

Sama Konwencja nr 154 nie ustanawia reguły wyłączności związków zawodowych w zakresie prowadzenia rokowań zbiorowych. Jednak postanowienia Konwencji nr 154 (art. 3 ust. 2) oraz Konwencji nr 135 MOP dotyczącej ochrony przedstawicieli pracowników w przedsiębiorstwach i przyznania im ułatwień (art. 5) zawierają wskazówki co do rozstrzygania sporów kompetencyjnych pomiędzy przedstawicielstwem związkowym a przedstawicielami wybieranymi w wolnych wyborach przez pracowników przedsiębiorstwa, zgodnie z przepisami ustawodawstwa krajowego lub układów zbiorowych, których funkcje nie obejmują działalności uznanej w danym kraju za wyłączną prerogatywę związków zawodowych, o których mowa w art. 3 lit. B Konwencji nr $135 \mathrm{MOP}^{7}$. Mianowicie jeżeli w przedsiębiorstwie istnieją zarówno przedstawiciele związków zawodowych, jak i przedstawiciele wybrani, państwa - strony konwencji zobowiązane są zapewnić, aby obecność przedstawicieli wybranych nie podważała pozycji zainteresowanych związków zawodowych lub ich przedstawicieli oraz w celu zachęcenia do współpracy pomiędzy przedstawicielami wybranymi a zainteresowanymi związkami zawodowymi i ich przedstawicielami we wszystkich należących do nich sprawach ${ }^{8}$. Normę tę można określić jako regułę prymatu związków zawodowych w sferze rokowań zbiorowych. Komitet Wolności Związkowej zaznacza, że w dziedzinie prowadzenia rokowań zbiorowych oznacza to, iż główną rolę przypisuje się organizacjom związkowym, a podmioty reprezentujące pracowników niezrzeszonych w związku zawodowym mogą prowadzić rokowania tylko wówczas, gdy związek zawodowy nie działa ${ }^{9}$. Natomiast bezpośrednie negocjacje pomiędzy pracodawcą i pracownikami z pominięciem organizacji związkowej działającej w zakładzie pracy w pewnych przypadkach mogą podważać zasadę promowania rokowań zbiorowych ${ }^{10}$. Także norma pozwalająca na prowadzenie rokowań zbiorowych w celu zawarcia układu zbiorowego przez delegatów załogi reprezentujących 10\% pracowników w przedsiębiorstwie, gdzie działa organizacja związkowa, nie sprzyja, w opinii Komitetu Wolności Związkowej, rozwojowi rokowań zbiorowych w rozumieniu art. 4 Konwencji nr 98 MOP, a ze względu na niewielki procent reprezentowanych pracowników może także podważać pozycje przedstawicieli pracowników, co nie jest zgodne z art. 3 ust. 2 Konwencji nr $154 \mathrm{MOP}^{11}$. Nie stanowi jednak naruszenia reguły prymatu związków zawodowych w zakresie prowadzenia rokowań zbiorowych złożenie propozycji podjęcia rokowań bezpośrednio niezwiązkowym przedstawicielom pracowników, gdy propozycja taka uprzednio złożona została organizacji związkowej i przez nią odrzucona, także

7 A.M. Świątkowski, Międzynarodowe prawo pracy..., s. 62.

${ }^{8}$ Zob. także International Labour Office Geneva, Freedom of Association. Digest of Decisions and Principles of the Freedom of Association Committee of the Governing Body of the ILO, Fifth (revised) ed., Geneva 2006, pkt. 945, s. 188; B. Gernigon, A. Odero, H. Guido, Collective Bargaining: ILO Standards and Principles of the Supervisory Bodies, Geneva 2000, s. 13.

9 Tamże, pkt 944, s. 188.

10 Tamże, pkt 945, s. 189.

11 Tamże, pkt 947, s. 189. 
w przypadku gdy następnie negocjacje pomiędzy pracodawcą a związkami zostały na nowo podjęte ${ }^{12}$. Rozstrzygnięcie takie jest istotne, zwłaszcza w przypadkach gdy działająca $w$ zakładzie pracy organizacja związkowa nie jest zainteresowana podjęciem rokowań zbiorowych. Jednocześnie postanowienia Konwencji nr 154 i Konwencji nr 135 pozwalają stwierdzić, że MOP uznaje za dopuszczalne prowadzenie rokowań zbiorowych z wybieranymi przedstawicielami pracowników tam, gdzie w ogóle związek zawodowy nie działa ${ }^{13}$.

Skuteczne uznanie prawa do rokowań pojawia się także jako jeden z podstawowych standardów pracy (core labour standards) obok swobody zrzeszania się, zniesienia wszelkich form pracy przymusowej, wykorzenienia pracy dzieci; zniesienia dyskryminacji w zatrudnieniu i życiu zawodowym w deklaracji dotyczącej podstawowych zasad i praw w pracy oraz działań uzupełniających, przyjętej w $1998 \mathrm{r}$. w następstwie Światowego Szczytu Społecznego, który odbył się w 1995 r. w Kopenhadze ${ }^{14}$. Deklaracja nie ma charakteru prawnie wiążącego. Podstawowe standardy w dziedzinie pracy zostały przez to „uwolnione" z konwencji, a jednocześnie ustanowiono nowy mechanizm ich przestrzegania gwarantujący, że państwa członkowskie MOP zobowiązane są do przestrzegania fundamentalnych zasad i praw ujętych w deklaracji bez względu na to, czy ratyfikowały odpowiednie konwencje ${ }^{15}$. Zasadom nadaje się tu zatem podobne szerokie znaczenie jak w Kartach Narodów Zjednoczonych, mają one szczególny status zasad o charakterze „konstytucyjnym”" ${ }^{16}$.

Można zatem stwierdzić, że na gruncie regulacji MOP prawo do rokowań zbiorowych nie stanowi wyłącznie jednego z aspektów wolności zrzeszania, a odrębne prawo przysługujące pracownikom. Mogą być oni reprezentowani przez związki zawodowe lub innych wybieranych przedstawicieli, z uwzględnieniem uprzywilejowanej pozycji przedstawicielstw związkowych.

12 Tamże, pkt 948, s. 189.

${ }_{13}$ A.M. Świątkowski, Międzynarodowe prawo pracy..., s. 64.

${ }_{14}$ J. Murray, The ILO and the Core Rights Discourse, w: Human Rights at Work. Perspectives on Law and Regulation, T. Novitz, C. Fenwick (red.), Oxford-Portland, Oregon, 2010, s. 363.

15 Tamże, s. 14; M. Matey-Tyrowicz, Podstawowe prawa społeczne $w$ dziedzinie pracy jako „mega-źródta" prawa pracy, w: M. Matey-Tyrowicz, T. Zieliński, Prawo pracy RP w obliczu przemian, Warszawa 2006, s. 57; C. Kaufmann, Globalisation and Labour Rights. The Conflict between Core Labour Rights and International Economic Law, Oxford 2007, s. 76; P. Alston, „Core Labour Standards”..., s. 26; Programme of Action of the World Summit for Social Development, $\$ 54(\mathrm{~b})$ „Safeguarding and promoting respect for basic workers' rights, including the prohibition of forced labour and child labour, freedom of association and the right to organize and bargain collectively, equal renumeration for men and women for work of equal value, and non-discrimination in employment, fully implementing the conventions of the International Labour Organization (ILO) in the case of States parties to those conventions, and taking into account the principles embodied in those conventions in the case of those countries that are not States parties to thus achieve truly sustained economic growth and sustainable development", http://www.un.org/esa/ socdev/wssd/text-version/agreements/poach3.htm (dostęp: 1.03.2017).

16 P. Alston, „Core Labour Standards”..., s. 28, 31. 


\section{Międzynarodowe Pakty Praw Człowieka}

Kolejne akty, na które wypada zwrócić uwagę, to Międzynarodowy Pakt Praw Obywatelskich i Politycznych (MPPOiP) ${ }^{17}$ oraz Międzynarodowy Pakt Praw Gospodarczych, Społecznych i Kulturalnych (MPPGSK $)^{18}$. MPPOiP w art. 22 gwarantuje każdemu prawo do swobodnego stowarzyszania się z innymi, włącznie z prawem do tworzenia i przystępowania do związków zawodowych w celu ochrony swych interesów. Nie odnosi się jednak do kwestii prowadzenia rokowań zbiorowych. Także Komitet Praw Człowieka sporadycznie jedynie formułował krytykę w odniesieniu do przypadków naruszenia prawa do strajku ${ }^{19}$. Szerszy zakres ochrony zbiorowych praw pracowniczych można odnaleźć w MPPGSK, a w szczególności w art. 8 ust. 1, który gwarantuje prawo każdego do tworzenia i przystępowania do związków zawodowych według własnego wyboru, w celu popierania i ochrony swych interesów gospodarczych i społecznych. Związkom zawodowym gwarantuje natomiast między innymi prawo do swobodnego wykonywania swej działalności oraz prawo do strajku ${ }^{20}$. Prowadzenie rokowań zbiorowych oraz zawieranie porozumień z całą pewnością mieści się w ramach wykonywania działalności związkowej. Wyraźnie widać jednak, że w świetle MPPGSK prawo to, stanowiąc emanację wolności związkowej, przyznawane jest organizacji związkowej, nie zaś samym pracownikom.

\section{Europejska Karta Społeczna}

Szczególną rolę w systemie aktów prawnych Rady Europy odgrywa Europejska Konwencja Praw Człowieka (EKPC) $)^{21}$, natomiast karty społeczne są traktatami międzynarodowymi, których celem jest lepsza ochrona praw socjalnych w Europie ${ }^{22}$. Zarówno konwencja, jak i karty powstały na fundamencie utworzonym przez Deklaracje Praw Człowieka $\mathrm{ONZ}^{23}$. W EKPC obok innych, nielicznych praw socjalnych wymieniona została wolność

17 Międzynarodowy Pakt Praw Obywatelskich i Politycznych z dnia 19 grudnia 1966 r. otwarty do podpisu w Nowym Jorku 19 grudnia 1966 r. (Dz. U. 1977, Nr 38, poz. 167).

18 Tamże, poz. 169.

19 S. Joseph, UN Conveants and Labour Rights, w: C. Fenwick, T. Novitz, Human Rights at Work: Perspectives on Law and Regulation, Oxford 2010, s. 350-351. Decyzja Komitetu Praw Człowieka z dnia 18 lipca 1986 r. w sprawie 118/1982 J.B. i inni p. Kanadzie oraz Uwagi końcowe z 1994 r. do sprawozdania z Meksyku CCPR/C/79/ Add. 32, pkt 10; Uwagi końcowe z 1996 r. do sprawozdania z Gwatemali CCPR/C/79/ Add. 63, pkt 18; Uwagi końcowe z 1997 r. do sprawozdania z Niemiec CCPR/C/79/ Add. 73 , pkt 18.

20 Zob. także L. Wiśniewski, Wolność zrzeszania się, w: Prawa człowieka. Model prawny, R. Wieruszewski (red.), Wrocław-Warszawa-Kraków 1991, s. 732.

${ }^{21}$ Konwencja o Ochronie Praw Człowieka i Podstawowych Wolności z dnia 4 listopada 1950 r. (Dz. U. 1993, Nr 61, poz. 284).

22 A.M. Świątkowski, Charter of Social Rights of the Council of Europe, Alphen a/d Rijn 2007, s. 51.

${ }^{23}$ M. Mikkola, Social Human Rights of Europe, Porvoo 2010, s. 52. 
zgromadzania się i stowarzyszania: w myśl art. 11 każdy ma prawo do swobodnego, pokojowego zgromadzenia się oraz do swobodnego stowarzyszania się, włącznie z prawem tworzenia związków zawodowych i przystępowania do nich w celu ochrony swoich interesów.

Europejska Karta Społeczna i Zrewidowana Europejska Karta Społeczna są uważane za odpowiedniki EKPC w sferze praw gospodarczych i społecznych ${ }^{24}$. Europejska Karta Społeczna Rady Europy (wersja z 1961 r.) jest pierwszym w skali światowej traktatem wielostronnym odnoszącym się do praw społecznych ${ }^{25}$. Pełni ona funkcję komplementarną w stosunku do Europejskiej Konwencji Ochrony Praw Człowieka i Podstawowych Wolności Rady Europy ${ }^{26}$. Ponad trzydzieści lat później EKS została poszerzona o nowy katalog praw ${ }^{27}$. Akt ten określa się często jako Zrewidowaną Europejską Kartę Społeczną (ZEKS). Polska ratyfikowała EKS z 1961 r. w 1997 r., natomiast zrewidowana karta nie została dotychczas ratyfikowana ${ }^{28}$. Warto nadmienić, że w systemie Kart Społecznych pierwotnej (EKS z 1961) i zrewidowanej (ZEKS z 1996) rozróżnia się dwie kategorie praw: (a) prawa kwalifikowane - te, spośród których ratyfikujące państwo musi wziąć na siebie określoną liczbę zobowiązań - stanowiące ścisły trzon normatywny (hard-core) oraz prawa pozostałe ${ }^{29}$. Do pierwszej grupy należą między innymi określone w art. 5 EKS i ZEKS prawo pracowników i pracodawców do swobodnego zrzeszania się w organizacjach krajowych lub międzynarodowych w celu ochrony ich interesów ekonomicznych i społecznych oraz określone w art. 6 EKS i ZEKS prawo pracowników i pracodawców do rokowań zbiorowych.

Zgodnie z art. 6 Europejskiej Karty Społecznej w celu zapewnienia skutecznego wykonywania prawa do rokowań zbiorowych Strony zobowiązują się: (1) popierać wspólne konsultacje pomiędzy pracownikami a pracodawcami; (2) popierać, kiedykolwiek będzie to konieczne i właściwe, mechanizm dobrowolnych negocjacji między pracodawcami lub organizacjami pracodawców z jednej strony a organizacjami pracowników z drugiej,

${ }^{24}$ J. Jaskiernia, Prawo Rady Europy a prawo krajowe - granice i wspólne obszary, w: Prawo międzynarodowe, europejskie i krajowe - granice i wspólne obszary. Ksiegg jubileuszowa dedykowana Profesor Genowefie Grabowskiej, B. Mikołajczyk, J. Nowakowska-Małusecka (red.), Katowice 2009, s. 259. Szerzej na temat kart zob. R. Blanpain, M. Matey-Tyrowicz, Europejskie prawo pracy w polskiej perspektywie, Warszawa 1993.

${ }^{25}$ J. Sozański, Prawa człowieka w Unii Europejskiej (po Traktacie Lizbońskim), Warszawa-Poznań 2009, s. 117.

${ }^{26}$ M. Matey-Tyrowicz, Podstawowe prawa społeczne w dziedzinie pracy..., s. 59.

${ }^{27} \mathrm{Na}$ marginesie wypada wspomnieć o szczególnym sposobie implementacji postanowień EKS, jakim jest ich wykonywanie w układach zbiorowych pracy na podstawie art. 33 EKS. L. Florek, Międzynarodowe źródła prawa pracy, w: Źródła prawa pracy, L. Florek (red.), Warszawa 2000, s. 69.

${ }^{28}$ M. Matey-Tyrowicz, Podstawowe prawa społeczne w dziedzinie pracy..., s. 59. Ratyfikacja ZEKS wymagałaby przeprowadzenia pewnych zmian w obowiązujących przepisach polskiego prawa pracy także w zakresie prawa do zrzeszania, prowadzenia sporów zbiorowych oraz prawa pracowników do informacji i konsultacji. A.M. Świątkowski, Zrewidowana Europejska Karta Społeczna - perspektywy ratyfikacji, Monitor Prawa Pracy 2006, 2.

${ }^{29}$ M. Matey-Tyrowicz, Podstawowe prawa społeczne w dziedzinie pracy..., s. 58-59. 
w celu uregulowania, w drodze układów zbiorowych pracy, warunków zatrudnienia; (3) popierać ustanowienie i wykorzystywanie właściwych mechanizmów pojednawczych oraz dobrowolnego arbitrażu w celu rozstrzygania sporów zbiorowych; (4) popierać prawo pracowników i pracodawców do zbiorowego działania w przypadku konfliktu interesów, włączając w to prawo do strajku, z zastrzeżeniem zobowiązań, jakie mogłyby wyniknąć z wcześniej zawartych układów zbiorowych pracy.

W zakresie konsultacji prawo do rokowań zbiorowych przyznawane jest pracownikom lub ich organizacjom, natomiast w odniesieniu do zawierania porozumień zbiorowych (układów zbiorowych pracy) art. $6 \$ 2$ EKS wyraźnie odnosi się do „organizacji pracowników"30. Nie budzi wątpliwości, że organizacjami takimi są związki zawodowe. Jednak w ostatnich latach w ramach procedury raportowania w decyzjach Europejskiego Komitetu Praw Społecznych (EKPS) dotyczących poszczególnych krajów pojawiają się przypadki regulacji krajowych dopuszczających zawieranie porozumień zbiorowych także przez inne niż związki zawodowe podmioty reprezentujące pracowników.

Za przykład może posłużyć treść raportu w sprawie Litwy, gdzie jeżeli w zakładzie pracy nie działa organizacja związkowa, a jej uprawnienia nie zostały przekazane reprezentatywnemu związkowi zawodowemu na poziomie sektorowym, układ zbiorowy może być zawarty przez radę pracowników ${ }^{31}$. W raporcie dla Ukrainy wskazano, że jeżeli jest więcej związków zawodowych, ich zrzeszeń lub innych ciał zaaprobowanych przez kolektyw pracowniczy w zakładzie pracy, w celu prowadzenia rokowań zbiorowych mają one stworzyć wspólną reprezentację. Jeżeli reprezentacja ta nie zdoła zawrzeć układu zbiorowego pracy, pracownicy na ogólnym zebraniu załogi przyjmą najodpowiedniejszy projekt układu zbiorowego i upoważnią delegata związkowego lub innego przedstawiciela do prowadzenia rokowań i zawarcia układu ${ }^{32}$. W tych przypadkach komitet zażądał dodatkowych informacji, nie sformułował więc konkluzji w zakresie zgodności regulacji krajowych z kartą. Nie poznajemy także opinii komitetu na temat relacji pomiędzy związkami zawodowymi a innymi ciałami przedstawicielskimi ${ }^{33}$.

W przypadku Francji pozwala się wybranym przedstawicielom pracowników i pracownikom upoważnionym przez związek zawodowy reprezentatywny na poziomie branżowym do zawierania porozumień w przedsiębiorstwach (nieobjętych branżowym układem zbiorowym), gdzie nie działają przedstawicielstwa związkowe. Liczba takich

${ }^{30}$ Zob. także European Council, Digest of the Case Law of The European Committee of Social Rights, September 2008, s. 53-54, https://rm.coe.int/CoERMPublicCommonSearchServices/DisplayDCTMCo ntent?documentId=090000168049159f (dostęp: 1.02.2017).

${ }^{31}$ Wnioski EKPS, Litwa, 2004, Art. $6 \$ 2$ EKS, http://hudoc.esc.coe.int/eng/\#\{,fulltext”:[„,bargainin g”],"ESCArticle”:[„06-02-000”],"ESCStateParty”:[„LTU”],"ESCDcIdentifier”:[„,2004/def/LTU/6/2/EN”]\} (dostęp: 10.02.2017).

${ }^{32}$ Wnioski EKPS, Ukraina, 2014, Art. $6 \$ 2$ EKS, http://hudoc.esc.coe.int/eng/\#\{„fulltext”:[„,barga ining”],"ESCArticle”:[„,06-02-000”],"ESCStateParty”:[„UKR”],"ESCDcIdentifier”:[„,2014/def/UKR/6/2/ EN"]\} (dostęp: 10.02.2017).

${ }_{33}$ Zob. K. Lörcher, Legal and Judicial International Avenues: The (Revised) European Social Charter, w: The Economic and Financial Crisis and Collective Labour Law in Europe, N. Bruun, K. Lörcher, I. Schömann (red.), Oxford-Portland, Oregon, 2014, s. 288. 
porozumień jest relatywnie niewielka, a Komitet Praw Społecznych uznał, że sytuacja we Francji jest zgodna z EKS ${ }^{34}$. W Armenii w przypadku braku związków zawodowych w zakładzie pracy lub gdy związek zawodowy nie zrzesza co najmniej połowy pracowników, zebranie załogi (konferencja) wybiera swoich przedstawicieli (ciało przedstawicielskie). Komitet przypomniał, że zgodnie z opinią Komitetu Ekspertów ds. Stosowania Konwencji i Zaleceń bezpośrednie negocjacje pomiędzy pracodawcą a pracownikami nie powinny prowadzić do pomijania związków zawodowych tam, gdzie one działają. W tym przypadku jednak komitet także powstrzymał się od wydania konkluzji3 ${ }^{35}$.

Wydaje się zatem, że Europejski Komitet Praw Społecznych, podobnie jak MOP, uznaje prymat organizacji związkowych przy prowadzeniu rokowań zbiorowych. Dopuszczenie innych wybranych przedstawicieli pracowników (w tym rad pracowników) do prowadzenia rokowań możliwe jest tylko wówczas, gdy nie prowadzi to do pominięcia działającej w zakładzie pracy organizacji związkowej. Jednak, jak widać na przykładzie wniosków w sprawie Francji, istnienie reguł pozwalających na prowadzenie rokowań przez przedstawicielstwo pozazwiązkowe jest zgodne z (Z)EKS.

\section{Europejska Konwencja Praw Człowieka}

Z ustalonego orzecznictwa Europejskiego Trybunału Praw Człowieka (ETPC) dotyczącego art. 11 Europejskiej Konwencji Praw Człowieka ${ }^{36}$ można wywieść następujące istotne składniki prawa do stowarzyszania się w związki zawodowe: prawo do tworzenia i przystępowania do związku zawodowego, zakaz porozumień closed shop, prawo związku zawodowego do podejmowania starań o przekonanie pracodawcy do wysłuchania jego argumentów, które przedstawia w imieniu swoich członków ${ }^{37}$. Trybunał podkreślił, że wykaz ten nie jest wyczerpujący. Przeciwnie, podlega ewolucji w zależności od zmian w stosunkach pracy ${ }^{38}$.

Jeszcze w orzeczeniu w sprawie UNISON przeciwko Zjednoczonemu Królestwu Trybunał stwierdził, że prawo do strajku lub zobowiązanie pracodawców do angażowania się w układy zbiorowe nie są ujęte w konwencji wprost. Co najwyżej art. 11 EKPC może

34 Wnioski EKPS, Francja, 2014, Art. $6 \$ 2$ EKS, http://hudoc.esc.coe.int/eng/\#\{„fulltext”:[„,barga ining”],"ESCArticle”:[„06-02-000”],"ESCStateParty”:[„„FRA”],"ESCDcIdentifier”:[„2014/def/FRA/6/2/ EN"]\} (dostęp: 1.03.2017).

${ }_{35}$ Wnioski EKPS, Armenia, 2014, Art. $6 \$ 2$ EKS, http://hudoc.esc.coe.int/eng/\#\{,,fulltext”:[„,bargai ning”],"ESCArticle”:[„06-02-000”],"ESCStateParty”:[„ARM”],"ESCDcIdentifier”:[„,2014/def/ARM/6/2/ EN"]\} (dostęp: 1.03.2017).

${ }^{36}$ Europejska Konwencja Praw Człowieka i Podstawowych Wolności; Europejska konwencja o ochronie praw człowieka i podstawowych wolności z dnia 4 listopada 1950 r., Dz. U. z 1993 r., Nr 61, poz. 284.

37 Zob. także Orzeczenie ETPC z 31 stycznia 2012 r. w sprawie Sindicatul „Păstorul Cel Bun” przeciwko Rumunii, skarga nr 2330/09, teza 135.

${ }^{38}$ M.A. Nowicki, Komentarz do art. 11 Konwencji o ochronie praw człowieka i podstawowych wolności, w: M.A. Nowicki, Wokół Konwencji Europejskiej. Komentarz do Europejskiej Konwencji Praw Człowieka, Lex 2010, nr 110309. 
być traktowany jako zabezpieczenie swobody związków zawodowych do działania w celu ochrony interesów zawodowych swoich członków ${ }^{39}$. Rozszerzenie prawa koalicji o uprawnienie do prowadzenia rokowań zbiorowych i inicjowanie strajku jest owocem najnowszych orzeczeń ETPC, który w wyroku w sprawie Demir i Baykara przeciwko Turcji ${ }^{40}$ dokonał wykładni pojęcia „prawa do tworzenia związków zawodowych i przystępowania do nich" zawartego w art. 11 EKPC, w taki sposób, że obejmuje ono także prawo do rokowań zbiorowych, w tym zawierania układów zbiorowych pracy ${ }^{41}$. Trybunał uznał, że jego orzecznictwo nie wyklucza, iż prawo do negocjacji zbiorowych z pracodawcą stanowi jeden z podstawowych środków (essencial means) dla związkowców do ochrony ich interesów. Zauważa w związku z tym, że istnieje organiczny związek pomiędzy wolnością zrzeszania się i wolnością prowadzenia rokowań zbiorowych. Trybunał powołał się przy tym na treść art. 5 i 6 Karty Społecznej i orzecznictwo Komitetu Niezależnych Ekspertów.

W uzasadnieniu omawianego wyroku trybunał wskazał, że ewolucję jego orzecznictwa w kwestii wysłowionej w art. 11 konwencji wolności stowarzyszania się w odniesieniu do związków zawodowych „wyznaczają dwie wiodące zasady: po pierwsze, trybunał bierze pod uwagę ogół środków uwzględnionych przez dane państwo, w granicach jego swobody decyzji, w celu ochrony wolności związkowej oraz, po drugie, że trybunał nie akceptuje ograniczeń, które dotykają istotnych elementów wolności związkowej, bez których wolność ta byłaby wyzuta $\mathrm{z}$ treści”" ${ }^{\text {" }}$. ETPC potwierdził tezę zawartą w wyroku w sprawie Wilson z 2002 r., że związek zawodowy musi w ten czy inny sposób mieć możliwość przedstawienia pracodawcy interesu swoich członków ${ }^{43}$. W wyroku w sprawie Demir i Baykara trybunał stwierdził w konkluzji, że rokowania zbiorowe, do których mają prawo związki zawodowe, stanowią $\mathrm{w}$ świetle prawa międzynarodowego oraz prawa państw-stron konwencji ,istotny środek promowania i ochrony interesów ich członków" ${ }^{\prime 4}$. Istotną cechą tego orzeczenia jest także metodologia trybunału, który w sposób systematyczny powołuje się na standardy międzynarodowe w zakresie ochrony praw pracowniczych, interpretując konwencję w świetle innych instrumentów międzynarodowych ${ }^{45}$.

${ }^{39}$ Orzeczenie ETPC z 10 stycznia 2002 r. w sprawie UNISON przeciwko Zjednoczonemu Królestwu, skarga nr 53574/99.

${ }^{40}$ Wyrok ETPC z 21 listopada 2006 r. w sprawie Demir i Baykara przeciwko Turcji, nr 34503/97.

${ }^{41} \mathrm{Na}$ szczególne znaczenie tego wyroku z polskiej perspektywy, ze względu na ograniczone prawo do zawierania układów zbiorowych pracy dla pracowników samorządowych zatrudnionych na podstawie wyboru, mianowania i powołania (art. $139 \$ 3 \mathrm{kp}$ ), zwraca uwagę W. Sanetra, Wyrok przeciwko Turcji a sprawa Polska, Praca i Zabezpieczenie Społeczne 2009, 5.

${ }^{42}$ Wyrok ETPC z 21 listopada 2006 r. w sprawie Demir i Baykara przeciwko Turcji, pkt. 144 sentencji.

${ }^{43}$ Wyrok ETPC w połączonych sprawach Wilson, National Union of Journalists i inni przeciwko Zjednoczonemu Królestwu, nr 30668/96, 30671/96 oraz 30678/96, pkt 41 sentencji.

${ }^{44}$ Wyrok ETPC z 21 listopada 2006 r. w sprawie Demir i Baykara przeciwko Turcji, pkt. 154 i 157 sentencji.

${ }^{45}$ Obszernej analizy metodologii ETPC dokonuje K. Lörcher, The New Social Dimension in the Jurisprudence of the European Court of Human Rights (ECtHR): The Demir and Baykara Judgement, Its 
Nie ulega wątpliwości, że na podstawie art. 11 EKPC prawo do rokowań zbiorowych rozpatrywane jest nie tyle jako prawo przysługujące samym pracownikom, ile jako jeden z aspektów działalności organizacji związkowej.

\section{Prawo Unii Europejskiej}

Prawa podstawowe zagwarantowane w Europejskiej Konwencji Praw Człowieka i Podstawowych Wolności oraz wynikające z tradycji konstytucyjnych wspólnych państwom członkowskim stanowią część prawa Unii jako zasady ogólne prawa (ust. 3). Kompetencje UE w zakresie prawa pracy są jednak ograniczone i nie obejmują między innymi prawa do zrzeszania się i prawa do strajku i lokautu ${ }^{46}$. Artykuły 152 i 153 TFUE odnoszą się do dialogu partnerów społecznych na poziomie europejskim, natomiast Karta Praw Podstawowych (KPP) zawiera także prawa socjalne, $w$ tym prawa w zakresie zbiorowego prawa pracy, żadne $\mathrm{z}$ nich nie jest jednak nowe ${ }^{47}$ : swoboda zrzeszania się i prowadzenia działalności związkowej uznawane były za prawa podstawowe już we wcześniejszym orzecznictwie TSUE ${ }^{48}$. W tytule IV pt. „Solidarność”, zawierającym większość praw socjalnych wymienionych w karcie, do zbiorowych praw pracowników odnoszą się zwłaszcza art. 27 i 28. Pierwszy z nich ustanawia prawo pracowników do informacji i konsultacji w ramach przedsiębiorstwa, natomiast artykuł $28 \mathrm{w}$ zakresie prawa do negocjowania i zawierania układów zbiorowych dotyczy prawa do rokowań i działań zbiorowych. Zgodnie z tym przepisem pracownicy i pracodawcy, lub ich odpowiednie organizacje, mają - zgodnie z prawem Unii oraz ustawodawstwami i praktykami krajowymi - prawo do negocjowania i zawierania układów zbiorowych pracy na odpowiednich poziomach oraz do podejmowania, w przypadkach konfliktu interesów, działań zbiorowych, w tym strajku, w obronie swoich interesów. Prawo do

Methodology and Follow up, w: F. Dorssemont, K. Lörcher, I. Schömann, The European Convention of Human Rights and the Employment Relation, Oxford 2013, s. 3-46.

${ }^{46}$ M. Matey-Tyrowicz, „Europeizacja” polskiego prawa pracy, w: System prawa RP w procesie europeizacji pod redakcja Marii Matey-Tyrowicz, Warszawa 2002, s. 168; T. Novitz, Giving with one Hand and Taking with the Other: Protection of Workers' Human Rights in the European Union, w: C. Fenwick, T. Novitz, Human Rights at Work: Perspectives on Law and Regulation, Oxford 2010, s. 466.

47 Szerzej na temat prawa pracy w KPP zob. P. Lorber, Labour Law, w: S. Peers, A. Ward, The European Charter of Fundamental Rights, Oxford 2004, s. 211 i n.

${ }_{48}$ T. Tridimas, The General Principles of EC Law, Oxford 1999, s. 210; B. Veneziani, The Need for Fundamental Social Rights, w: Prawo pracy a wyzwania XXI wieku. Ksiega jubileuszowa Profesora Tadeusza Zielińskiego, Matey-Tyrowicz M., Nowacki L., Wagner B. (red.), Warszawa 2002, s. 650. Zob. orzeczenia w sprawach C-415/93 Union Royale Belge (Wyrok Trybunału z 15 grudnia 1995 r. w sprawie C-415/93 Union Royale Belge des Sociétés de Football Association ASBL przeciwko Jean-Marc Bosman, Royal Club Liégeois SA v. Jean-Marc Bosman and others and Union des Associations Européennes de Football (UEFA) przeciwko Jean-Marc Bosman, European Court Reports 1995 I-04921 i Union Syndicale Massa i Kortner (Wyrok Trybunału z 8 października 1974 r. w sprawie 175-73 Union syndicale - Amalgamated European Public Service Union - Brussels, Denise Massa i Roswitha Kortner przeciwko Radzie Wspólnot Europejskich, European Court Reports 1974-00917). 
rokowań zbiorowych chronione jest zatem zarówno w art. 12 KPP (jako aspekt wolności zrzeszania się, zgodnie z interpretacją art. 11 EKPC przyjętą przez ETPC), jak i w art. 28 KPP. Pierwszy z przepisów karty bez wątpienia ustanawia „prawo”. Natomiast przepisy art. 27 i $28 \mathrm{KPP}$ proponuje się zaliczyć do grupy przepisów „hybrydalnych”, to jest zawierających zarazem elementy praw i zasad ${ }^{49}$.

Ponadto wśród instrumentów unijnego prawa wtórnego można wymienić dyrektywy: 98/59/WE z 20 lipca 1998 r. w sprawie zbliżania ustawodawstw państw członkowskich, odnoszących się do zwolnień grupowych (Dz. U. WE L, Nr 225, s. 16), 2001/23/WE z 12 marca 2001 r. w sprawie zbliżania ustawodawstw Państw Członkowskich odnoszących się do ochrony praw pracowniczych w przypadku przejęcia przedsiębiorstw, zakładów lub części przedsiębiorstw lub zakładów (Dz. U. WE L, Nr 82, s. 16). Dyrektywy implementowane do polskiego porządku prawnego ${ }^{50}$ przewidują możliwość zawierania porozumień zbiorowych. Akty te, wraz z dyrektywami dotyczącymi prawa do informacji i konsultacji ${ }^{51}$, uważane są za istotne elementy modelu rokowań zbiorowych w sprawach związanych $\mathrm{z}$ indywidualnym stosunkiem pracy $^{52}$.

W Dyrektywie 98/59/WE dotyczącej zwolnień grupowych zobowiązuje się pracodawcę, który ma zamiar dokonać zwolnień grupowych, do przeprowadzenia we właściwym czasie konsultacji z przedstawicielami pracowników w celu osiągnięcia porozumienia (art. 2 ust. 1 Dyrektywy 98/59/WE). Przez przedstawicieli pracowników rozumieć należy przedstawicieli przewidzianych przez prawodawstwo lub praktykę Państw Członkowskich [art. 1 ust. 1 b) dyrektywy].

W Dyrektywie 2001/23/WE dotyczącej przejęcia przedsiębiorstwa przewidziana jest możliwość uzgodnienia takich zmian warunków pracy pracowników, na jakie zezwalają

49 I. Kamiński, Karta Praw Podstawowych jako połaczenie praw i zasad - strukturalna wada czy szansa, w: Karta Praw Podstawowych w europejskim i krajowym porządku prawnym, A. Wróbel (red.), Warszawa 2009, s. 44.

${ }^{50}$ J. Wratny, Prawo pracowników do informacji i konsultacji - dyrektywa wspólnotowa a projekt polskiej ustawy, Monitor Prawa Pracy 2005, 2; Tenże, Geneza i główne rozwiązania ustawy z 7.04.2006 r. o informowaniu pracowników i przeprowadzaniu z nimi konsultacji, Monitor Prawa Pracy 2006, 12; K. Niedzielska, Partycypacja pracowników w spółce europejskiej z siedziba w Polsce - etap negocjacyjny, Monitor Prawa Pracy 2005, 5; Taż, Partycypacja pracowników w spółce europejskiej z siedziba w Polsce - informowanie, konsultowanie oraz uczestnictwo w organach spótki, Monitor Prawa Pracy 2005, 6; A. Mietek, Zaangażowanie pracowników w spótce europejskiej - uwagi „de lege ferenda”, Monitor Prawa Pracy 2014, 7; E. Skibińska, Zaangażowanie pracowników w spółdzielni europejskiej, Monitor Prawa Pracy 2006, 10; R. Markowska-Wolert, Zaangażowanie pracowników w spółce europejskiej, Praca i Zabezpieczenie Społeczne 2005, 7; D. Skupień, Europejskie rady zakładowe, Toruń 2008; B. Skulimowska, Ustawa o europejskich radach zakładowych, Monitor Prawa Pracy 2004, 2; D. Skupień, Europejskie rady zakładowe - nowa forma partycypacji pracowniczej w zarządzaniu na gruncie prawa polskiego, w: M. Królikowska-Olczak, Prawo europejskie w systemie polskiej gospodarki, Warszawa 2005.

${ }^{51}$ Szczególne znaczenie mają dyrektywy określające: obowiązek pracodawcy informowania pracowników o warunkach umowy lub stosunku pracy (Dyrektywa 91/533/EWG), informację i konsultację pracowników (Dyrektywa 2002/14/WE) oraz funkcjonowanie europejskich rad zakładowych (Dyrektywa 2009/38/WE).

52 B. Bercusson, European Labour Law, Cambridge 2009, s. 336. 
obowiązujące przepisy i praktyka, mających zapewnić możliwości ochrony zatrudnienia poprzez zapewnienie możliwości przetrwania przedsiębiorstwa lub zakładu względnie części przedsiębiorstwa lub zakładu pomiędzy przejmującym, zbywającym lub osobą albo osobami wykonującymi funkcje zbywającego $z$ jednej strony i przedstawicielami pracowników z drugiej strony. Przy czym przez przedstawicieli pracowników należy rozumieć, podobnie jak w Dyrektywie 98/59/WE, przedstawicieli przewidzianych przez prawodawstwo lub praktykę Państw Członkowskich.

Prawo do rokowań zbiorowych pojawiało się także w orzecznictwie Trybunału Sprawiedliwości Unii Europejskiej (TSUE). Można tu wymienić na przykład wyrok w sprawie Albany ${ }^{53}$, gdzie trybunał stwierdzał, że wprawdzie pewne skutki w postaci ograniczenia konkurencji są nieodłączne od porozumień zbiorowych zawieranych między reprezentatywnymi organizacjami pracodawców i pracobiorców, jednakże realizacja celów z zakresu polityki społecznej, jakim służą tego rodzaju porozumienia, byłaby poważnie zagrożona, gdyby partnerzy społeczni podlegali art. 85 ust. 1 traktatu, poszukując wspólnie sposobów poprawienia warunków zatrudnienia i pracy.

Co ciekawe, w późniejszym wyroku w sprawie Viking odnoszącym się do realizacji uprawnień przez związki zawodowe w kontekście swobody przepływu osób i usług trybunał stwierdził, że usunięcie przeszkód w swobodnym przepływie osób i w swobodnym przepływie usług między państwami członkowskimi byłoby nieskuteczne, gdyby w miejsce usuniętych barier państwowych mogły pojawiać się przeszkody wynikające z wykonywania przez związki lub organizacje niepodlegające prawu publicznemu swojej autonomii prawnej ${ }^{54}$. Z tego też powodu trybunał potraktował organizacje związkowe, które na drodze rokowań zbiorowych kształtują obowiązki pracodawców w ramach stosunku pracy, tak jak podmioty publiczne, podporządkowując ich działalność normom traktatowym ${ }^{55}$. Tę linię orzecznictwa, pozwalającą na ingerencję w krajowe systemy stosunków przemysłowych w zakresie prawa do rokowań zbiorowych, TSUE zdaje się podtrzymywać także w sprawie Alemo Herron dotyczącej objęcia układem zbiorowym pracy pracowników przejmowanego przedsiębiorstwa ${ }^{56}$.

Zatem także i w świetle prawa UE prawo do prowadzenia rokowań zbiorowych zdaje się przysługiwać pracownikom reprezentowanym przez związki zawodowe lub innych przedstawicieli pracowników.

${ }^{53}$ Wyrok Trybunału z dnia 21 września 1999 r. w sprawie C-67/96 Albany International BV przeciwko Stichting Bedrijfspensioenfonds Textielindustrie. Zbiór Orzeczeń 1999 I-05751.

${ }^{54}$ Wyrok Trybunału (wielka izba) z dnia 11 grudnia 2007 r. w sprawie C-438/05 International Transport Workers' Federation i Finnish Seamen's Union przeciwko Viking Line ABP i OÜ Viking Line Eesti. Zbiór Orzeczeń 2007 I-10779 (pkt 57).

55 Sprawa C36/02 (pkt 65).

${ }^{56}$ Wyrok Trybunału (trzecia izba) z dnia 18 lipca 2013 r. w sprawie C426/11 Mark Alemo-Herron i in. przeciwko Parkwood Leisure Ltd, ECLI:EU:C:2013:521, teza 37. Zob. także N. Busby, R. Zahn, The EU and the ECHR: Collective and Non-discrimination Labour Rights at Crossroad, International Journal of Comparative Labour Law and Industrial Relations 2014, 30 (2), s. 169, 172. 


\section{Prawo krajowe}

W polskim prawie krajowym prawo do prowadzenia rokowań oraz do zawierania układów zbiorowych pracy i innych porozumień zostało wymienione w art. 59 ust. 2 Konstytucji RP wprost, stanowiąc jeden z elementów wolności zrzeszania się w związkach zawodowych i organizacjach pracodawców. Układy te, wraz z opartymi na ustawie porozumieniami zbiorowymi, statutami i regulaminami (w szczególności regulaminem pracy i wynagradzania) stanowią tak zwane swoiste (autonomiczne) źródła prawa pracy ${ }^{57}$. Układ zbiorowy pracy jest umową między pracodawcą lub organizacją pracodawców a organizacją związkową lub organizacjami związkowymi, określającą warunki, jakim powinna odpowiadać treść stosunków pracy pracowników objętych układem, wzajemne zobowiązania stron układu oraz inne sprawy nieuregulowane w przepisach prawa pracy w sposób bezwzględnie obowiązujący ${ }^{58}$. Podczas prowadzenia rokowań oraz zawierania układu zbiorowego pracy pracowników oraz osoby wykonujące prace na innej podstawie niż stosunek pracy mogą być reprezentowane wyłącznie przez związek zawodowy.

${ }^{57}$ Za powszechnie obowiązującym charakterem postanowień układów zbiorowych pracy i uznaniem ich za źródło prawa pracy wypowiadają się między innymi W. Szubert, Układy zbiorowe pracy, Warszawa 1960, s. 18; L. Florek, Zgodność przepisów prawa pracy z Konstytucją, Praca i Zabezpieczenie Społeczne 1997, 11, s. 11; G. Goździewicz, Układy zbiorowe pracy jako źódło prawa pracy, w: Układy zbiorowe pracy. W stulecie urodzin profesora Wacława Szuberta, Z. Góral (red.), Warszawa 2013, s. 80; przeciwko natomiast L. Kaczyński, Wpływ art. 87 Konstytucji na swoiste źródła prawa pracy (uwagi wstępne), Państwo i Prawo 1997, 8, s. 66-67 oraz Tenże, Układ zbiorowy pracy - problem konstytucyjny, Państwo i Prawo 1999, 8, s. 11. Zob. także G. Goździewicz, Refleksje na temat charakteru prawnego układu zbiorowego pracy, w: Wolność i sprawiedliwość w zatrudnieniu. Księga poświęcona Prezydentowi Rzeczypospolitej Polskiej Profesorowi Lechowi Kaczyńskiemu, M. Seweryński, J. Stelina (red.), Gdańsk-Sopot 2012, s. 117-118. Jednak zdaniem Arkadiusza Sobczyka nie ma powodów merytorycznych, aby układom i porozumieniom zbiorowym przyznać przymiot prawa, co więcej, ustalenia zbiorowe nie zmieniają prawa. Ustalenia takie kreują tylko cywilnoprawne, umowne i równoległe do instytucji ustawowych zobowiązania pracodawcy. Zdaniem tego autora Kodeks pracy jako ustawa nie może definiować tego, co jest źródłem prawa, ponieważ katalog źródeł prawa zawarty został w Konstytucji RP. Dialog nie musi wcale polegać na tworzeniu prawa, a samo uprawnienie do prowadzenia rokowań zbiorowych nie jest jednoznaczne z nadaniem związkom zawodowym, jako profesjonalnym podmiotom negocjującym umowy na rzecz pracowników, uprawnienia do tworzenia prawa, a przedmiotem porozumień zbiorowych (w tym układów zbiorowych pracy) jest negocjowanie warunków umowy i zagwarantowanie ich stabilności. Wszystkie nieustawowe źródła prawa pracy kształtują treść umów i należy traktować je jako wzorce umowne, o których mowa w art. $384 \mathrm{kp}$, związki zawodowe zaś pełnią rolę pełnomocnika ustawowego uprawnionego do reprezentowania pracowników na podstawie art. 7 ustawy o związkach zawodowych oraz 59 ust. 2 Konstytucji RP (A. Sobczyk, Prawo pracy w świetle Konstytucji RP, t. II, Wybrane problemy $i$ instytucje prawa pracy a konstytucyjne prawa $i$ wolności człowieka, Warszawa 2013, s. 129-145).

58 Z. Hajn, Zbiorowe prawo pracy..., s. 15. 
Obok zarejestrowanych układów zbiorowych pracy, zawieranych zarówno na poziomie zakładowym, jak i ponadzakładowym, partnerzy społeczni mogą zawierać także inne porozumienia. Są to umowy partnerów społecznych dotyczące indywidualnych i zbiorowych praw i obowiązków pracowników i pracodawców ${ }^{59}$. U tych pracodawców, u których nie funkcjonuje przynajmniej jedna zakładowa lub międzyzakładowa organizacja związkowa, mogą działać przedstawiciele pracowników wyłaniani w trybie przyjętym u danego pracodawcy. Jest to więc forma reprezentacji praw i interesów pracowników zastępcza, subsydiarna wobec związków zawodowych ${ }^{60}$.

Istotne jest przy tym, że ustawodawca posługuje się bardzo niejednorodnym nazewnictwem, określając podmiot wybrany ad hoc, jako na przykład przedstawiciele pracowników wyłonieni w trybie przyjętym u tego pracodawcy $\left(\operatorname{art} .67^{6} \mathrm{kp}\right.$, art. $150 \$ 3$ ust. $2 \mathrm{kp}$ ), przedstawiciele pracowników wybierani w trybie przyjętym w zakładzie pracy (np. art. $237^{13} \mathrm{a} \mathrm{kp}$ ); przedstawiciele pracowników bez wskazywania sposobu ich wyboru (np. art. $145 \mathrm{kp}$ ). Niekiedy więc może być to przedstawicielstwo jednoosobowe, innym razem ustawodawca wymaga reprezentacji wieloosobowej ${ }^{61}$. W tym miejscu wypada zauważyć, iż w nauce prawa pracy budzi wątpliwości zagadnienie reprezentowania pracowników w sytuacji, kiedy ustawodawca wymaga powołania przedstawicielstwa pracowniczego przez wybraną wcześniej radę pracowników. Zdaje się jednak przeważać pogląd, zgodnie z którym rada pracowników nie posiada kompetencji w takim zakresie jak przedstawiciele pracowników wybierani $a d$ hoc, a kompetencje te nie powinny być automatycznie przez radę przejmowane ${ }^{62}$.

${ }^{59}$ K. Jaśkowski, Porozumienia zbiorowe w prawie pracy, w: Indywidualne a zbiorowe prawo pracy, L. Florek (red.), Warszawa 2007, s. 82.

${ }^{60}$ J. Stelina, Zbiorowa reprezentacja pracowników w Polsce - stan obecny i perspektywy, w: Problemy kodyfikacji prawa pracy. Wybrane zagadnienia zabezpieczenia społecznego. Referaty na XVI Zjazd Katedr oraz Zakładów Prawa Pracy i Ubezpieczeń Społecznych, Gdańsk, 19-21 września 2007 roku, A. Kubicka (red.), Gdańsk 2007, s. 97; na temat relacji przedstawicielstw związkowych i pozazwiązkowych zob. J. Stelina, Związki zawodowe a pozazwiązkowe przedstawicielstwo pracowników w zakładzie pracy, w: Związkowe przedstawicielstwo pracowników zakładu pracy, Z. Hajn (red.), Warszawa 2012, s. 170 i n. oraz M. Smusz-Kulesza, Konkurencja uprawnień informacyjnych realizowanych przez związkowe i niezwiązkowe przedstawicielstwa pracownicze, w: Związkowe przedstawicielstwo pracowników zakładu pracy, Z. Hajn (red.), Warszawa 2012, s. 327 i n.

61 A. Sobczyk, Przedstawicielstwa pozazwiązkowe w systemie zbiorowej reprezentacji pracowników - stan obecny i kierunki zmian, w: Zbiorowe prawo pracy w XXI wieku, J. Stelina, M. Tomaszewska, A. Wypych-Żywicka (red.), Gdańsk 2010, s. 215. Na marginesie wypada zwrócić uwagę na problemy związane $\mathrm{z}$ brakiem ochrony trwałości stosunku pracy tych osób, mimo że w świetle prawa międzynarodowego, jako przedstawiciele pracowników, ochronie podlegać powinni. M. Gładoch, Uczestnictwo pracowników w zarządzaniu przedsiębiorstwem w Polsce. Problemy teorii i praktyki na tle prawa wspólnotowego, Toruń 2008, s. 201; M.B. Rycak, Szczególna ochrona trwałości stosunku pracy przedstawicieli pracowników, w: Związki zawodowe a niezwiązkowe przedstawicielstwa pracownicze w gospodarce posttransformacyjnej, J. Wratny, M. Bednarski (red.), Warszawa 2010, s. 162-164.

62 A. Sobczyk, Przedstawicielstwa pozazwiązkowe..., s. 221; B. Wagner, Porozumienia zawierane na gruncie ustawy o informowaniu pracowników i przeprowadzaniu z nimi konsultacji, w: A. Sobczyk (red.), Informowanie i konsultacja pracowników w polskim prawie pracy, A. Sobczyk (red.), Kraków 2008, s. 121122; A. Pabisiak, M. Wojewódka, w: Zbiorowe prawo pracy. Komentarz, J. Wratny, K. Walczak (red.), 
Spośród porozumień partnerów społecznych opartych na ustawie związkom zawodowym przyznano wyłączność $\mathrm{w}$ zakresie zawierania porozumień na podstawie ustawy o rozwiązywaniu sporów zbiorowych - po rokowaniach bądź mediacji, związanych z przejściem zakładu pracy lub jego części na innego pracodawcę na podstawie art. $26^{1}$ ustawy o związkach zawodowych. Natomiast wśród porozumień, do których zawierania uprawnieni są przedstawiciele pracowników, można wymienić porozumienia dotyczące:

1) zawieszania przepisów prawa pracy (art. $\left.9^{1} \mathrm{kp}\right)$;

2) zawieszania stosowania postanowień umownych (art. $\left.23^{1} \mathrm{kp}\right)$;

3) wprowadzenia regulaminu telepracy $\left(\operatorname{art} .67^{6} \mathrm{kp}\right)$;

4) bezpieczeństwa i higieny pracy: zawarcia porozumienia w sprawie wykazu prac pracowników pracujących w nocy (art. $151^{7} \mathrm{kp}$ );

5) w ramach procedury zwolnień grupowych: ustalenia zasad postępowania w sprawach dotyczących pracowników objętych zamiarem grupowego zwolnienia (art. 3 ustawy o szczególnych zasadach rozwiązywania z pracownikami stosunków pracy z przyczyn niedotyczących pracowników);

6) ustalenia systemów i rozkładów czasu pracy oraz wprowadzenia przedłużonego okresu rozliczeniowego czasu pracy (art. $150 \mathrm{kp}$ ).

Porozumienia zawierane przez partnerów społecznych, które nie mają oparcia w ustawie, zostały zakwalifikowane przez judykaturę do kategorii nienazwanych umów zbiorowego prawa pracy. Indywidualne roszczenia pracowników mające swoje źródło w takiej umowie wynikają z możliwości potraktowania jej - zgodnie $\mathrm{z}$ art. $300 \mathrm{kp}$ - jako umowy na rzecz osoby trzeciej ( $\operatorname{art} .393 \mathrm{kc}^{63}$ ), na podstawie której pracownicy niebędący stroną porozumienia mogą żądać spełnienia przyrzeczonego świadczenia bezpośrednio od pracodawcy jako podmiotu, który przyjął na siebie w umowie z partnerem społecznym (zakładową organizacją związkową) obowiązek takiego świadczenia na rzecz pracowników ${ }^{64}$.

W odniesieniu do porozumień zawieranych przez wybieranych przedstawicieli pracowników na poziomie przedsiębiorstwa tylko te, które zostały wymienione wprost $\mathrm{w}$ ustawie, mogą być traktowane jak źródła prawa pracy w rozumieniu art. $9 \$ 1 \mathrm{kp}$. W tym kontekście L. Florek wywodzi, że dominująca ostatnio w orzecznictwie SN nadinterpretacja przepisu art. 59 ust. 2 Konstytucji RP (który gwarantuje tylko prawo „do zawierania układów zbiorowych pracy i innych porozumień", bez przesądzania o ich normatywnym bądź umownym charakterze) jest wykładnią contra legem, ponieważ art. $9 \$ 1$ kp rozróżnia dwa rodzaje porozumień: mające charakter źródła prawa pracy i pozbawione tej cechy ${ }^{65}$.

Warszawa 2009, SIP Legalis (dostęp: 20.02.2016). Nieco mniej kategoryczne stanowisko w tej sprawie zajmuje natomiast L. Florek, Prawo pracowników do informacji i konsultacji, Monitor Prawa Pracy 2006, 5, s. 240.

${ }^{63}$ Ustawa z dnia 23 kwietnia 1964 r. Kodeks Cywilny tekst jedn. Dz. U. z 2014 r., poz. 121.

${ }^{64}$ A.M. Świątkowski, Komentarz do art. 9 k.p., w: tenże, Kodeks pracy. Komentarz, wyd. 4, Warszawa 2012, SIP Legalis (dostęp: 1.03.2017).

${ }^{65}$ L. Florek, Ustawa i umowa w prawie pracy, Warszawa 2010, s. 303. 
W prawie polskim prawo do prowadzenia rokowań zbiorowych i zawierania porozumień przyznawane jest zatem przede wszystkim związkom zawodowym. Jedynie w sytuacji, gdy w zakładzie pracy brak reprezentacji związkowej, dopuszcza się do działania inne przedstawicielstwa pracownicze.

\section{Ponadnarodowe porozumienia zbiorowe}

Coraz większego znaczenia, ze względu na częste powiązania pomiędzy przedsiębiorstwami krajowymi a przedsiębiorstwami działającymi na terenie innych krajów, nabierają ponadnarodowe rokowania zbiorowe obejmujące dialog zarówno na poziomie sektorowym, jak i przedsiębiorstwa ${ }^{66}$. Może on przybierać formę wymiany istotnych, z perspektywy rokowań zbiorowych, informacji na poziomie ponadnarodowym przez pracodawców i pracowników. Z kolei rokowania ponadnarodowe owocują przyjęciem wspólnych tekstów i porozumień ramowych o bardziej „miękkim” lub „twardym” charakterze ${ }^{67}$.

Porozumienia ponadnarodowe różnią się od siebie także terytorialnym zakresem regulacji: niektóre z nich mają zasięg globalny (International Framework Agreement, IFA $)^{68}$, inne zaś obejmują przedsiębiorstwa działające na terenie UE.

W ujęciu proponowanym przez Komisję Europejską porozumienie ponadnarodowe (TCA) oznacza porozumienie zawierające wzajemne zobowiązania, których zakres obejmuje terytorium kilku krajów i które zostały zawarte przez jednego lub więcej przedstawicieli przedsiębiorstwa lub grupy przedsiębiorstw z jednej strony oraz jedną lub więcej organizację związkową z drugiej oraz które dotyczą warunków pracy i zatrudnienia lub relacji pomiędzy pracodawcą a pracownikami lub ich przedstawicielami ${ }^{69}$.

W kontekście tego opracowania szczególnie istotna jest zauważalna różnorodność podmiotów zawierających porozumienia ponadnarodowe. Po stronie pracowników mogą być to europejskie rady zakładowe, które często inicjują zawarcie porozumienia i stają się

${ }^{66}$ Dalsze rozważania dotyczące porozumień ponadnarodowych zostały zaprezentowane pierwotnie w opracowaniu J. Unterschütz, Ponadnarodowe porozumienia zbiorowe w świetle zasady pokoju społecznego, Praca i Zabezpieczenie Społeczne 2015, 8, s. 3-8.

${ }^{67}$ R. Jagodziński, Transnational Collective Bargaining: A Literature Review, w: I. Schömann, R. Jagodziński, G. Boni, S. Clauwaert, V. Glassner, T. Jaspers, Transnational Collective Bargaining at Company Level. A New Component of European Industrial Relations?, Bruksela 2012, s. 43.

${ }_{68}$ Zob. S. Adamczyk, B. Surdykowska, Międzynarodowe układy ramowe jako przykład dobrowolnie podejmowanych negocjacji między praca a kapitałem, w: Układy zbiorowe pracy. W stulecie urodzin Profesora Wacława Szuberta, Z. Góral (red.), Warszawa 2013, s. 131 passim. K. Papadakis, Globalizing Industrial Relations: What Role for International Framework Agreements?, w: The Role of Collective Bargaining in the Global Economy. Negotiating for Social Justice, I.S. Hayter (red.), Geneva 2011, s. 278.

${ }^{69}$ Commission Staff Working Document, The Role of Transnational Company Agreements in the Context of Increasing International Integration, COM (2008) 419 final, http://eur-lex.europa.eu/legalcontent/EN/TXT/PDF/?uri=CELEX:52008SC2155\&from=EN (dostęp: 27.03.2014). 
jego stroną (szczególnie w przypadku porozumień europejskich) ${ }^{70}$, choć ich kompetencje w tym zakresie budzą wątpliwości. Pracownicy mogą być także reprezentowani przez europejskie i międzynarodowe federacje związkowe, których rola jest znacząca zwłaszcza w przypadku porozumień o charakterze globalnym. Krajowe organizacje związkowe są natomiast aktywne przede wszystkim w procesie wdrażania postanowień porozumień ponadnarodowych na poziomie przedsiębiorstwa, ale także bywają stroną podpisującą porozumienia o charakterze globalnym ${ }^{71}$.

Na gruncie prawa polskiego porozumienia te można zaliczyć w zdecydowanej większości przypadków do grupy porozumień niemających oparcia w ustawie.

\section{Uwagi końcowe}

Analiza regulacji międzynarodowych i krajowych nie pozwala jednoznacznie stwierdzić, iż prawo do rokowań zbiorowych przyznawane jest wyłącznie organizacjom związkowym. Podobny pogląd wyraża TK w jednym z orzeczeń dotyczących obowiązywania układów zbiorowych pracy, gdzie zwraca uwagę na społeczną funkcję prawa do rokowań zbiorowych: „,...] prawo to jest nie tylko środkiem realizacji interesów związków zawodowych i związków pracodawców; przede wszystkim służy ono realizacji interesów pracowników i pracodawców"72.

Jednocześnie daje się zauważyć, że zarówno na tle regulacji krajowych, jak i przywołanych wyżej aktów prawa międzynarodowego prawo do rokowań zbiorowych, nieco odmiennie niż przysługujące samym pracownikom prawo do informacji i konsultacji, postrzegane jest jako jeden $\mathrm{z}$ aspektów wolności zrzeszania się. W myśl reguły prymatu reprezentacji związkowej inni niż związkowi przedstawiciele pracowników dopuszczani są do działania jedynie w zastępstwie organizacji związkowej tam, gdzie zawarcie porozumienia sprzyja zagwarantowaniu interesu pracowników (np. zwolnienia grupowe), a brak reprezentacji związkowej lub istniejąca nie chce przejąć inicjatywy w negocjacjach $\mathrm{z}$ pracodawcą.

Co do zasady w polskim prawie pracy negocjacje i zawieranie porozumień są przejawem reprezentowania i obrony praw oraz interesów pracowniczych, do czego powołane są związki zawodowe. Uznaje się, że pozbawienie związków zawodowych

70 A. Sobczak, E. Leonard, Transnational Social Dialogue at the Sector and the Company Level, Wystąpienie na konferencji „Regulating for decent work: innovative regulation as a response to globalization", International Labour Office, Geneva, Switzerland 8-10 July 2009, s. 4, http://www.ilo.org/legacy/english/protection/travail/pdf/rdwpaper44b.pdf (dostęp: 1.03.2017), s. 7.

${ }^{71}$ Commission Staff Working Document, The Role of Transnational Company Agreements..., s. 8; É. Léonard, A. Sobczak, Accords transnationaux d'entreprise et dialogue social sectoriel européen: quelles interactions?, Travail et Emploi 2010, 121, s. 45.

${ }^{72}$ Wyrok TK w sprawie K 37/01. J. Unterschütz, Naczelne zasady zbiorowego prawa pracy w multicentrycznym porządku prawnym, Gdynia 2016, s. 264. 
wyłączności w zakresie negocjowania i zawierania układów zbiorowych pracy naruszyłoby niewątpliwie ich szczególną pozycję i siłę oddziaływania na stosunki pracy ${ }^{73}$.

Nawet w szerokim ujęciu prawa do rokowań zbiorowych, dokonywanym przez TK chociażby w judykatach z $2000^{74}$ i $2009 \mathrm{r}^{75}$, niezmiennie związane jest ono z aktywnością partnerów społecznych - przedstawicieli pracowników. Prawo to zatem nie może być realizowane przez pracowników bezpośrednio. Prowadzenie negocjacji i zawieranie porozumień przez niewielką grupę pracowników działających w swoim interesie pozbawiałoby to działanie jego „zbiorowego", dokonywanego w interesie szerszego ogółu, charakteru.

Niestety, ze względu na niski poziom uzwiązkowienia ${ }^{76}$ polski model rokowań zbiorowych nie daje możliwości korzystania z tego prawa znacznej liczbie pracowników. Problem ten zyskuje na aktualności w świetle dynamicznych zmian obserwowanych na rynku pracy w ostatnim dziesięcioleciu. Obok dobrze znanych nietypowych form zatrudnienia, takich jak telepraca czy zatrudnienie za pośrednictwem agencji pracy tymczasowej, employee sharing (zatrudnienie pracownika u kilku pracodawców), job sharing (wykonywanie pracy na jednym stanowisku przez dwóch lub więcej pracowników zatrudnionych w niepełnym wymiarze pracy $)^{77}$, pojawiają się nowe, związane także z rozwojem gospodarki cyfrowej formy wykonywania pracy, jak na przykład praca z wykorzystaniem technologii teleinformatycznych czy platform internetowych ${ }^{78}$. Wspólną cechą najnowszych zjawisk jest wykonywanie pracy poza zakładem pracy,

${ }^{73}$ G. Goździewicz, Układy zbiorowe pracy jako podstawowy..., s. 104-105. W tym miejscu autor zauważa również, że zwolennicy dopuszczenia także innych, aniżeli związkowe, przedstawicielstw pracowniczych do negocjacji i zawierania układów zbiorowych pracy wskazują na możliwość realnego oddziaływania pracowników na poziom swoich uprawnień oraz ochronę praw i interesów. Przy zachowaniu obecnego status quo większość zatrudnionych pozbawionych jest takiej możliwości.

${ }^{74}$ Wyrok TK z 13 marca 2000 r. K 1/99, OTK 2000, nr 2, poz. 59; Wyrok TK w sprawie K 45/04; Wyrok TK w sprawie P 50/07; Postanowienie TK z 18 listopada 2002 r. K 37/01, OTK Seria A 2002, nr 5, poz. 71, Dz. U. z 2002 r., Nr 196, poz. 660.

75 Wyrok TK z dnia 28 kwietnia 2009 r., K 27/07, Dz. U. z 2009 r., Nr 68, poz. 584, s. 5491, OTK Seria A 2009 , nr 4, poz. 54. „[...] »Prawo do rokowań« w tym rozumieniu oznacza prawo do wyrażania opinii związków zawodowych we wszystkich sprawach dotyczących praw i obowiązków pracowników. Nie ogranicza się ono zatem wyłącznie do prawa do wyrażenia swojego stanowiska w toku rozwiązywania sporów zbiorowych i zawierania układów zbiorowych pracy”. Podstawą rozstrzygnięcia jest tu także analiza orzecznictwa ETPC (który stopniowo poszerzał sposób rozumienia prawa związków zawodowych do rokowań zbiorowych jako jednego z kluczowych elementów wolności stowarzyszania się pracowników w celu ochrony ich praw) oraz art. 6 Europejskiej Karty Społecznej.

${ }^{76}$ Według danych GUS osoby zrzeszone w związkach zawodowych stanowiły $5 \%$ dorosłej ludności Polski, $11 \%$ - w odniesieniu do wszystkich osób pracujących, $17 \%$ - zatrudnionych na podstawie stosunku pracy oraz 19\% - pracowników zakładów pracy zatrudniających powyżej 9 osób. Główny Urząd Statystyczny, Notatka informacyjna. Związki zawodowe w Polsce w 2014 r., Warszawa, 13.07.2015 r., http:// stat.gov.pl/download/gfx/portalinformacyjny/pl/defaultaktualnosci/5490/10/1/1/notatka_zz_1007_ost. pdf (dostęp: 1.06.2017).

77 A. Chobot, Nowe formy zatrudnienia. Kierunki rozwoju i nowelizacji, Warszawa 1997, s. 146-147.

${ }_{78}$ Eurofound, New Forms of Employment, Publications Office of the European Union, Luxembourg 2010. 
często w miejscach geograficznie odległych, przez pracowników, którzy w celu wykonania zadań nie muszą utrzymywać z sobą kontaktu. To znacznie utrudnia tworzenie wspólnej reprezentacji związkowej, zwłaszcza w systemie, w którym ustawodawca zdaje się czynić założenie, zgodnie z którym organizacje związkowe tworzone są u pracodawcy ${ }^{79}$. Brak reprezentacji związkowej oznacza konsekwentnie brak możliwości prowadzenia rokowań zbiorowych w celu zawarcia układu zbiorowego pracy lub innego porozumienia, którego stroną jako przedstawiciel pracowników może być tylko organizacja związkowa.

Konieczne zatem wydaje się wprowadzenie zmian w dziedzinie zbiorowego prawa pracy.

Idąc w ślad za szeroką interpretacją zwrotu „oparte na ustawie porozumienia zbiorowe”, prezentowaną w niektórych judykatach SN, można by proponować poszerzenie możliwości zawierania porozumień zbiorowych na inne przedstawicielstwa pracownicze. Jednak takie dowartościowanie porozumień zbiorowych podważyłoby pozycję układów zbiorowych pracy, na przykład przez możliwość ich zmiany lub zastąpienia przez porozumienie zawarte przez mniejszościową i mało znaczącą organizację związkową ${ }^{81}$. Stanowi to poważne zagrożenie „ładu normatywnego” w zbiorowych stosunkach pracy. System źródeł prawa może bowiem zostać rozsadzony przez przypadkowe porozumienia zawierane przez różne strony, które nie są objęte żadną regulacją prawną ani kontrolą ich zgodności z prawem ${ }^{82}$.

Inna możliwość to rozszerzenie prawa do rokowań zbiorowych na inne podmioty (np. rady pracowników), co być może pozwoliłoby korzystać z prawa do rokowań zbiorowych szerszym rzeszom pracowników, wiążąc się jednocześnie z osłabieniem pozycji związków zawodowych. Rozwiązanie takie budzi jednak wątpliwości ze względu na słabą dynamikę tworzenia nowych rad pracowników. Od 2011 r. (to jest od roku następującego po wprowadzeniu zmian do ustawy o informowaniu pracowników i przeprowadzaniu z nimi konsultacji w zakresie tworzenia rad pracowników) utworzono około 350 nowych rad pracowników spośród liczby około 3500 nowo powstałych $\operatorname{rad}^{83}$. Pozwala to przypuszczać, że w wielu przypadkach to właśnie związki zawodowe były inicjatorami tworzenia tych przedstawicielstw pracowników.

Warto pamiętać, że szczególna pozycja związków zawodowych znajduje także oparcie w Konstytucji RP. Jak wskazuje TK w judykacie z 2015 r.,

79 Problem ten nie dotyczy oczywiście wyłącznie sytuacji polskich pracowników tymczasowych, o czym pisze między innymi M. Weiss w Re-inventing Labour Law, w: G. Davidov, B. Langille, The Idea of Labour Law, Oxford 2011, s. 48.

${ }^{80}$ Zob. Wyrok SN z 28 kwietnia 2005 r., I PK 214 /04, OSNP z 2006, nr 1-2, poz. 8; Uchwała SN z 23 maja 2001 r., III ZP 25/00, OSNP z 2002 r., nr 6, poz. 134; wyrok SN z 12 grudnia 2001 r., I PKN 729/00, OSNP z 2003 r., nr 23, poz. 568; wyrok SN z 12 sierpnia 2004 r., III PK 38/04, OSNP z 2005 r., nr 4, poz. 55; uchwała SN z 23 maja 2006 r., III PZP 2/06, OSNP z 2007 r., nr 3-4, poz. 38; wyrok SN z 28 kwietnia 2005 r., I PK 214/04, OSNP z 2006 r., nr 1-2, poz. 8.

${ }^{81}$ Z. Hajn, Zbiorowe prawo pracy..., s. 37.

${ }^{82}$ L. Florek, Ustawa i umowa w prawie pracy, s. 309.

${ }^{83}$ Spis rad pracowników - stan na dzień 28. 02.2017 r. dostępny na stronie dialog.gov.pl, http://www. dialog.gov.pl/dialog-krajowy/informowanie-i-konsultowanie/rady-pracownikow/ (dostęp: 1.06.2017). 
[...] wyodrębnienie związków zawodowych i organizacji pracodawców w art. 59 ust. 1 Konstytucji spośród innych form zrzeszania się, a następnie przyznanie tym podmiotom szczególnych uprawnień, wiąże się z ukierunkowaniem ich działalności na realizację konkretnego celu. Jest nim ochrona interesów osób wykonujących pracę zarobkową i pracodawców. Wyraźna identyfikacja tego celu oraz powierzenie jego realizacji wskazanym typom podmiotów stanowiących formy zrzeszania się jednostek wiąże się z przyjętą w Konstytucji koncepcją ustrojową ${ }^{84}$.

Wśród szczególnych celów działania organizacji związkowych spośród wszelkich innych form zrzeszania się obywateli zwraca uwagę ETPC: celem ustanowienia wolności zrzeszania w art. 11 EKPC jest umożliwienie pracownikom, aby ich „głos został wysłuchany”, czemu służą specyficzne uprawnienia organizacji związkowej, jak prawo do prowadzenia rokowań zbiorowych oraz prawo do strajku ${ }^{85}$.

Z całą pewnością niezbędne jest zatem rozszerzenie prawa koalicji w ustawie o związkach zawodowych także na inne grupy osób wykonujących pracę zarobkową, tak aby objęte nim zostały, jak wskazuje TK w wyroku w sprawie K 1/13, wszystkie podmioty, które

[...] charakteryzuje przede wszystkim fakt wykonywania pracy zarobkowej na czyjąś rzecz oraz posiadanie interesów zawodowych, które mogą być grupowo chronione przez związek zawodowy. Nie ma w tym kontekście istotnego znaczenia to, w jakiej formie i na jakiej podstawie dana osoba świadczy pracę zarobkową ${ }^{86}$.

Ponadto dla zakładów pracy, w których nie działa zakładowa organizacja związkowa, celowe być może utworzenie instytucji delegata związkowego, który mógłby reprezentować interesy załogi.

Prawo do rokowań zbiorowych jako jedna z naczelnych zasad prawa pracy powiązane jest ściśle z zasadą swobody koalicji - związkowa ochrona interesów pracowniczych nie byłaby możliwa bez prawa do rokowań zbiorowych oraz prawa do strajku, a także zasadą ograniczonej roli państwa w zbiorowych stosunkach pracy ${ }^{87}$. Swoboda prowadzenia rokowań zbiorowych oraz zawierania porozumień pozwala pracodawcom i pracownikom na kształtowanie wzajemnych relacji w postaci obowiązujących norm postępowania ${ }^{88}$. Prawo do prowadzenia rokowań zbiorowych stanowi także jeden $\mathrm{z}$ aspektów zasady dialogu społecznego, a zawieranie porozumień będących owocem rokowań służy zapewnieniu pokoju społecznego: rokowania jako tryb zawierania porozumień zbiorowych uznaje

84 Wyrok TK z dnia 2 czerwca 2015 r. K 1/13, pkt. 3.3 uzasadnienia.

85 Zob. wyrok ETPC w połączonych sprawach Wilson, National Union of Journalists i inni przeciwko Zjednoczonemu Królestwu, nr 30668/96, 30671/96 oraz 30678/96, pkt 44 sentencji; Wyrok ETPC z 21 listopada 2006 r. w sprawie Demir i Baykara przeciwko Turcji, nr 34503/97, pkt. 9 sentencji.

86 Wyrok TK z dnia 2 czerwca 2015 r. K 1/13, pkt. 7.2 uzasadnienia.

87 L. Florek, Ustawa i umowa w prawie pracy, s. 250. Więcej na temat naczelnych zasad zbiorowego prawa pracy J. Unterschütz, Naczelne zasady zbiorowego prawa pracy..., s. 105-172.

88 G. Goździewicz, Podstawowe zasady zbiorowego prawa pracy, w: Zbiorowe prawo pracy w społecznej gospodarce rynkowej, G. Goździewicz (red.), Toruń 2000, s. 53. 
się za szczególną wartość prawa układowego, ponieważ służą one uzyskaniu konsensusu między partnerami społecznymi, często za cenę kompromisu. Pozwalają uwzględnić różne interesy partnerów społecznych. Natomiast celem nadrzędnym, a więc nadrzędną wartością prawa układowego w zakresie rokowań, jest osiągnięcie pokoju społecznego ${ }^{89}$. W zmieniającym się świecie pracy, w którym nowe formy zatrudnienia wiążą się nie tylko z pożądaną przez pracowników i samych pracodawców elastycznością, lecz także niejednokrotnie $\mathrm{z}$ niskimi zarobkami ${ }^{90}$, należy poszukiwać form organizacji, które pozwolą im na skuteczne prowadzenie rokowań zbiorowych.

\section{Bibliografia}

Adamczyk S., Surdykowska B., Międzynarodowe układy ramowe jako przykład dobrowolnie podejmowanych negocjacji między praca a kapitałem, w: Układy zbiorowe pracy. W stulecie urodzin Profesora Wacława Szuberta, Z. Góral (red.), Warszawa 2013, s. 131.

Alston P., "Core Labour Standards" and the Transformation of the International Labour Rights Regime, w: V.A. Leary, D. Warner, Social Issues, Globalisation and International Institutions. Labour Rights and the EU, ILO, OECD and WTO, Leiden-Boston 2006.

Bercusson B., European Labour Law, Cambridge 2009.

Blanpain R., Matey-Tyrowicz M., Europejskie prawo pracyw polskiej perspektywie, Warszawa 1993. Busby N., Zahn R., The EU and the ECHR: Collective and Non-discrimination Labour Rights at Crossroad, International Journal of Comparative Labour Law and Industrial Relations 2014, 30 (2).

Chobot A., Nowe formy zatrudnienia. Kierunki rozwoju i nowelizacji, Warszawa 1997.

Eurofound, New Forms of Employment, Publications Office of the European Union, Luxembourg 2010.

Florek L., Zgodność przepisów prawa pracy z Konstytucją, Praca i Zabezpieczenie Społeczne 1997, 11.

Florek L., Międzynarodowe źródła prawa pracy, w: Źródła prawa pracy, L. Florek (red.), Warszawa 2000.

Florek L., Prawo pracowników do informacji i konsultacji, Monitor Prawa Pracy 2006, 5.

Florek L., Ustawa i umowa w prawie pracy, Warszawa 2010.

Gernigon B., Odero A., Guido H., Collective Bargaining: ILO Standards and Principles of the Supervisory Bodies, Geneva 2000.

Gładoch M., Uczestnictwo pracowników w zarządzaniu przedsiębiorstwem w Polsce. Problemy teorii i praktyki na tle prawa wspólnotowego, Torun 2008.

${ }^{89}$ T. Wyka, Znaczenie prawa o układach zbiorowych pracy dla pozaukładowych porozumień zbiorowych, w: Prawo pracy. Refleksje i poszukiwania. Ksiega jubileuszowa Profesora Jerzego Wratnego, G. Uścińska (red.), Warszawa 2013, s. 142.

${ }_{90}$ Eurofound, New Forms of Employment... s. 115. 
Goździewicz G., Podstawowe zasady zbiorowego prawa pracy, w: Zbiorowe prawo pracy w społecznej gospodarce rynkowej, G. Goździewicz (red.), Toruń 2000.

Goździewicz G., Układy zbiorowe pracy jako podstawowy instrument działalności związków zawodowych, w: Zbiorowe prawo pracy w XXI wieku, J. Stelina, M. Tomaszewska, A. Wypych-Żywicka (red.), Gdańsk 2010.

Goździewicz G., Refleksje na temat charakteru prawnego układu zbiorowego pracy, w: Wolność i sprawiedliwość w zatrudnieniu. Księga poświęcona Prezydentowi Rzeczypospolitej Polskiej Profesorowi Lechowi Kaczyńskiemu, M. Seweryński, J. Stelina (red.), Gdańsk-Sopot 2012.

Goździewicz G., Układy zbiorowe pracy jako źródło prawa pracy, w: Układy zbiorowe pracy. W stulecie urodzin Profesora Wacława Szuberta, Z. Góral (red.), Warszawa 2013.

Hajn Z., Zbiorowe prawo pracy. Zarys systemu, Warszawa 2013.

International Labour Office Geneva, Freedom of Association. Digest of Decisions and Principles of the Freedom of Association Committee of the Governing Body of the ILO, Fifth (revised) ed., Geneva 2006, pkt. 945.

Jagodziński R., Transnational Collective Bargaining: A Literature Review, w: I. Schömann, R. Jagodziński, G. Boni, S. Clauwaert, V. Glassner, T. Jaspers, Transnational Collective Bargaining at Company Level. A New Component of European Industrial Relations?, Bruksela 2012.

Jaskiernia J., Prawo Rady Europy a prawo krajowe - granice $i$ wspólne obszary, w: Prawo międzynarodowe, europejskie i krajowe - granice i wspólne obszary. Księga jubileuszowa dedykowana Profesor Genowefie Grabowskiej, B. Mikołajczyk, J. Nowakowska-Małusecka (red.), Katowice 2009.

Jaśkowski K., Porozumienia zbiorowe w prawie pracy, w: Indywidualne a zbiorowe prawo pracy, L. Florek (red.), Warszawa 2007.

Joseph S., UN Conveants and Labour Rights, w: C. Fenwick, T. Novitz, Human Rights at Work: Perspectives on Law and Regulation, Oxford 2010.

Kaczyński L., Wpływ art. 87 Konstytucji na swoiste źródła prawa pracy (uwagi wstępne), Państwo i Prawo 1997, 8.

Kaczyński L., Układ zbiorowy pracy - problem konstytucyjny, Państwo i Prawo 1999, 8.

Kamiński I., Karta Praw Podstawowych jako połaczenie praw i zasad - strukturalna wada czy szansa, w: Karta Praw Podstawowych w europejskim i krajowym porzadku prawnym, A. Wróbel (red.), Warszawa 2009.

Kaufmann C., The Conflict between Core Labour Rights and International Economic Law, Oxford 2007.

Kaufmann C., Globalisation and Labour Rights. The Conflict between Core Labour Rights and International Economic Law, Oxford 2007.

Léonard É., Sobczak A., Accords transnationaux d'entreprise et dialogue social sectoriel européen: quelles interactions?, Travail et Emploi 2010, 121.

Lorber P., Labour Law, w: S. Peers, A. Ward, The European Charter of Fundamental Rights, Oxford 2004.

Lörcher K., The New Social Dimension in the Jurisprudence of the European Court of Human Rights (ECtHR): The Demir and Baykara Judgement, Its Methodology and Follow up, w: 
F. Dorssemont, K. Lörcher, Isabelle Schömann, The European Convention of Human Rights and the Employment Relation, Oxford 2013.

Lörcher K., Legal and Judicial International Avenues: The (Revised) European Social Charter, w: The Economic and Financial Crisis and Collective Labour Law in Europe, N. Bruun, K. Lörcher, I. Schömann (red.), Oxford-Portland, Oregon, 2014.

Markowska-Wolert R., Zaangażowanie pracowników w spółce europejskiej, Praca i Zabezpieczenie Społeczne 2005, 7.

Matey-Tyrowicz M., „Europeizacja” polskiego prawa pracy, w: System prawa RP w procesie europeizacji pod redakcja Marii Matey-Tyrowicz, Warszawa 2002.

Matey-Tyrowicz M., Podstawowe prawa społeczne w dziedzinie pracy jako „mega-źródła” prawa pracy, w: M. Matey-Tyrowicz, T. Zieliński, Prawo pracy RP w obliczu przemian, Warszawa 2006.

Mietek A., Zaangażowanie pracowników w spółce europejskiej - uwagi „de lege ferenda”, Monitor Prawa Pracy 2014, 7.

Mikkola M., Social Human Rights of Europe, Porvoo 2010.

Murray J., Taking Social Rights Seriously: Is there a Case for Institutional Reform of the ILO?, w: Human Rights at Work. Perspectives on Law and Regulation, T. Novitz, C. Fenwick (red.), Oxford-Portland, Oregon, 2010.

Murray J., The ILO and the Core Rights Discourse, w: Human Rights at Work. Perspectives on Law and Regulation, T. Novitz, C. Fenwick (red.), Oxford-Portland, Oregon, 2010.

Niedzielska K., Partycypacja pracowników w spółce europejskiej z siedziba w Polsce - etap negocjacyjny, Monitor Prawa Pracy 2005, 5.

Niedzielska K., Partycypacja pracowników w spółce europejskiej z siedziba w Polsce - informowanie, konsultowanie oraz uczestnictwo w organach spółki, Monitor Prawa Pracy 2005, 6.

Novitz T., Giving with one Hand and Taking with the Other: Protection of Workers' Human Rights in the European Union, w: C. Fenwick, T. Novitz, Human Rights at Work: Perspectives on Law and Regulation, Oxford 2010.

Nowicki M.A., Komentarz do art. 11 Konwencji o ochronie praw człowieka i podstawowych wolności, w: M.A. Nowicki, Wokół Konwencji Europejskiej. Komentarz do Europejskiej Konwencji Praw Człowieka, Lex 2010, nr 110309.

Pabisiak A., Wojewódka M., w: Zbiorowe prawo pracy. Komentarz, J. Wratny, K. Walczak (red.), Warszawa 2009, SIP Legalis.

Papadakis K., Globalizing Industrial Relations: What Role for International Framework Agreements?, w: The Role of Collective Bargaining in the Global Economy. Negotiating for Social Justice, I.S. Hayter (red.), Geneva 2011.

Rycak M.B., Szczególna ochrona trwałości stosunku pracy przedstawicieli pracowników, w: Związki zawodowe a niezwiazkowe przedstawicielstwa pracownicze w gospodarce posttransformacyjnej, J. Wratny, M. Bednarski (red.), Warszawa 2010.

Sanetra W., Wyrok przeciwko Turcji a sprawa Polska, Praca i Zabezpieczenie Społeczne 2009, 5. Skibińska E., Zaangażowanie pracowników w spółdzielni europejskiej, Monitor Prawa Pracy 2006, 10.

Skulimowska B., Ustawa o europejskich radach zakładowych, Monitor Prawa Pracy 2004, 2. 
Skupień D., Europejskie rady zakładowe - nowa forma partycypacji pracowniczej w zarzadzaniu na gruncie prawa polskiego, w: M. Królikowska-Olczak, Prawo europejskie w systemie polskiej gospodarki, Warszawa 2005.

Skupień D., Europejskie rady zakładowe, Torun 2008.

Smusz-Kulesza M., Konkurencja uprawnień informacyjnych realizowanych przez związkowe i niezwiązkowe przedstawicielstwa pracownicze, w: Związkowe przedstawicielstwo pracowników zakładu pracy, Z. Hajn (red.), Warszawa 2012.

Sobczak A., Leonard E., Transnational Social Dialogue at the Sector and the Company Level, Wystąpienie na konferencji „Regulating for decent work: innovative regulation as a response to globalization", International Labour Office, Geneva, Switzerland 8-10 July 2009.

Sobczyk A., Przedstawicielstwa pozazwiązkowe w systemie zbiorowej reprezentacji pracowników - stan obecny i kierunki zmian, w: Zbiorowe prawo pracy w XXI wieku, J. Stelina, M. Tomaszewska, A. Wypych-Żywicka (red.), Gdańsk 2010.

Sobczyk A., Prawo pracy w świetle Konstytucji RP, t. II, Wybrane problemy i instytucje prawa pracy a konstytucyjne prawa $i$ wolności człowieka, Warszawa 2013.

Sozański J., Prawa człowieka w Unii Europejskiej (po Traktacie Lizbońskim), Warszawa-Poznań 2009.

Stelina J., Zbiorowa reprezentacja pracowników w Polsce - stan obecny i perspektywy, w: Problemy kodyfikacji prawa pracy. Wybrane zagadnienia zabezpieczenia społecznego. Referaty na XVI Zjazd Katedr oraz Zakładów Prawa Pracy i Ubezpieczeń Społecznych, Gdańsk, 19-21 września 2007 roku, A. Kubicka (red.), Gdańsk 2007.

Stelina J., Związki zawodowe a pozazwiązkowe przedstawicielstwo pracowników w zakładzie pracy, w: Związkowe przedstawicielstwo pracowników zakładu pracy, Z. Hajn (red.), Warszawa 2012.

Szubert W., Układy zbiorowe pracy, Warszawa 1960.

Świątkowski A.M., Zrewidowana Europejska Karta Społeczna - perspektywy ratyfikacji, Monitor Prawa Pracy 2006, 2.

Swiątkowski A.M., Charter of Social Rights of the Council of Europe, Alphen a/d Rijn 2007.

Świątkowski A.M., Międzynarodowe prawo pracy, t. I, Międzynarodowe publiczne prawo pracy. Wolumen 1, Warszawa 2008.

Świątkowski A.M., Komentarz do art. 9 k.p., w: tenże, Kodeks pracy. Komentarz, wyd. 4, Warszawa 2012, SIP Legalis.

Tridimas T., The General Principles of EC Law, Oxford 1999.

Unterschütz J., Ponadnarodowe porozumienia zbiorowe w świetle zasady pokoju społecznego, Praca i Zabezpieczenie Społeczne 2015, 8.

Unterschütz J., Naczelne zasady zbiorowego prawa pracy w multicentrycznym porządku prawnym, Gdynia 2016.

Veneziani B., The Need for Fundamental Social Rights, w: Prawo pracy a wyzwania XXI wieku. Księga jubileuszowa Profesora Tadeusza Zielińskiego, Matey-Tyrowicz M., Nowacki L., Wagner B. (red.), Warszawa 2002.

Wagner B., Porozumienia zawierane na gruncie ustawy o informowaniu pracowników i przeprowadzaniu z nimi konsultacji, w: A. Sobczyk (red.), Informowanie i konsultacja pracowników w polskim prawie pracy, A. Sobczyk (red.), Kraków 2008. 
Weiss M., Re-inventing Labour Law, w: G. Davidov, B. Langille, The Idea of Labour Law, Oxford 2011.

Wiśniewski L., Wolność zrzeszania się, w: Prawa człowieka. Model prawny, R. Wieruszewski (red.), Wrocław-Warszawa-Kraków 1991.

Wratny J., Prawo pracowników do informacji i konsultacji - dyrektywa wspólnotowa a projekt polskiej ustawy, Monitor Prawa Pracy 2005, 2.

Wratny J., Geneza i główne rozwiązania ustawy z 7.04.2006 r. o informowaniu pracowników i przeprowadzaniu z nimi konsultacji, Monitor Prawa Pracy 2006, 12.

Wyka T., Znaczenie prawa o układach zbiorowych pracy dla pozaukładowych porozumień zbiorowych, w: Prawo pracy. Refleksje i poszukiwania. Ksiega jubileuszowa Profesora Jerzego Wratnego, G. Uścińska (red.), Warszawa 2013. 



\title{
Krzysztof Baran
}

Katedra Prawa Pracy i Polityki Społecznej

Wydział Prawa i Administracji

Uniwersytet Jagielloński

\section{RESTRICTIONS ON THE RIGHT TO INFORMATION IN THE ACTIVITY OF WORKS COUNCILS}

\begin{abstract}
This article discusses restrictions on the right to information in the activity of works councils regulated in the Act of 7 April 2006 on information and consultation of employees, which are justified by legitimate interests of the employer and the right to keep certain information confidential. First of all, it analyzes the obligation not to disclose trade secrets by the members of works council and other persons as well as consequences of breach by an employee of the aforesaid confidentiality obligation. Subsequently, the author discusses the employer's right to refuse to provide information to the works council, which is limited by the fulfilment of certain conditions. Finally, the paper presents the measure that workers' council has at its disposal in the event of unjustified reservation by the employer of confidentiality of the information or refusal to provide such information.
\end{abstract}

Słowa kluczowe: rada pracowników, prawo do informacji, tajemnica przedsiębiorstwa

Key words: works council, right to information, trade secret

The right to information is a cornerstone of collective labour relations. The relevant rights are granted not only to trade unions but also to participation bodies, including works councils. It is worth emphasizing that in the Polish labour law system the right to information is not absolute and was significantly restricted under article 16 of the act of 7 April 2006 on information and consultation of employees (ustawa o informowaniu pracowników i prowadzeniu z nimi konsultacji) (further called the I\&C Act).

Article 16 (1) of the I\&C Act sets out the rules governing the trade secrecy in the information and consultation procedures. ${ }^{1}$ At the personal level it is addressed to members of works council, its experts and workers' representatives authorised under the agreement concluded in accordance with article 24 of the act in question. In my opinion the fact

1 See J. Borowicz, Przestrzeganie tajemnicy pracodawcy a inne pracownicze obowiazki przestrzegania tajemnicy - zagadnienia pojęciowe (Employer's secrecy and other obligations to observe confidentiality), Praca i Zabezpieczenie Społeczne 1998, 10, p. 3 ff. 